\title{
Administrative Paradigms on the Human Factor in the Public Administration of México
}

\author{
Luis Arturo Marín Aboytes ${ }^{1 *}$, Josefina Morgan Beltrán ${ }^{2}$ \\ ${ }^{I}$ PhD student in Administration at the Autonomous University of Querétaro, Master in Administration and \\ Bachelor of Administrator and Bachelor of Law. \\ ${ }^{2} \mathrm{PhD}$ in Administration and post-doctorate in Education, research professor at the Autonomous University of \\ Querétaro, Mexico
}

*Corresponding Author: Luis Arturo Marín Aboytes, PhD student in Administration at the Autonomous University of Querétaro, Master in Administration and Bachelor of Administrator and Bachelor of Law.

\begin{abstract}
The aim is to analyze the integration of a new profile of the human factor in the field of public service, with characteristics different from the established paradigms within the bureaucratic system of government public administration. The current practice of the classic precepts of bureaucratic theory has arrived. to a state of operational obsolescence since its design was created with paradigms according to its time, without considering its relationship with the environment where it was executed and not with the change in the environment with the new generations and their needs and paradigms according to a time postmodern, they lead to reflection on its operational efficiency, generating the proposal of deconstruction of the same for its adaptability to the new environment and current labor-force generations, especially the one known as the "millennial". It is a documentary and field research, with a qualitative approach, the results allow us to propose a "Neo-bureaucracy" that is adjusted to current paradigms, without losing the essence of the bureaucracy established by the classics of public administration, thus achieving the objective of a deconstruction for the improvement of the bureaucratic system of public administration.
\end{abstract}

Key words: Bureaucracy, public administration, Neobureaucracy, Millennial

\section{INTRODUCTION}

Nowadays, a generational change can be observed from various social aspects, both in the way in which one interacts derived from technological advances and also in the politics and public life of the country.

The new generation called "millennials" is marked by advances and growing technological changes, such as the use of social networks, forming an integral part of their public and private life. In these circumstances, it is necessary to rethink new horizons of insertion of this generation into the Mexican bureaucracy and to integrate the different generations that coexist in the workplace, seeking to obtain the best from each one. Due to the adaptation of young people to virtual platforms, it is essential to establish policies that allow them to act and work from the technological field, since today it is distant to speak of a traditional bureaucracy and merely paperwork, since the new generations demand to the State a renewal both in public policies and in its own organizational and work form.

The objective of the research work is the explanation of a proposal as a new adjustment and complement to the theory of organizational systems currently in force for the government bureaucratic structure, thereby achieving the permanence of the new human factor within the same system, thus giving the opportunity to propose new paths for future research on labor and organizational issues.

Among the questions addressed in this research are: Will Max Weber's classic bureaucratic model be what the public administration still requires? What visions of work does the IMF and ILO provide? How is it implemented in our country? in order that with the contributions of the same, the 
establishment of positions on the importance of this new generation and the transversal relationship with current technological advances is encouraged.

\section{THEORETICAL APPECTS}

\subsection{Millennials}

For this research, the concept presented by Bongiovanni (2016, p. 17) about Millennials will be discussed, which is the one that generally has the following characteristics:

- Deinstitutionalization. They do not believe in institutions, rather they value people individually.

- Openness: They value diversity in all its forms (political, racial, religious, sexual, age, family, etc.) and have a deep awareness of social responsibility, care for the environment and justice.

- Innovation: They have a greater development of the right side of the brain, which guides them to be more creative, enterprising and emotional. They enjoy the new and the feeling of freedom.

- Computerization: They have a strong command of information technology and the use of social networks, mobile phones, etc. that facilitates communication and socialization.

- Self-esteem and power: They have high self-esteem and self-confidence, with tendencies towards hedonism. They feel powerful about handling information. They are people of action who need to be protagonists.

- Commitment: Responsibility and involvement appear "only if" they perceive that their contribution is worth, in which case they are ready for fast and practical learning.

- Socialization, teamwork and comparative: They are aware of teamwork and are not inhibited by hierarchical structures. They feel like active parts of a team. They compare their performance with their peers, to fully exploit their talent.

- Short-term and Time Valuation: They live the present with intensity without worrying so much about the future, they have grown up in a world of rapid changes. They value and seek to optimize time in order to do what they like, this generation seeks a balance between work and private life (work and enjoy), understanding work as a means to achieve well-being and not as an end in itself. They are pragmatic and aided by the mastery of technology, they can simultaneously attend to work and personal matters.

For Millennials, work does not only mean money, but rather it is interpreted as an experience. It is also important to note that it also means a space for entertainment and socialization (Cuesta, 2012).

It is important to analyze the value that they give to the extra salary benefits, more than $95 \%$ will indicate having benefits. And of the most mentioned and most powerful are the "casual day" (casual day by its definition from English), which refers to a day in which employees can express themselves in their way of dressing, using casual clothing instead of work uniforms, and the "home office" (home office for its expression in English) which is working, within working hours, from home, which gives you the allowance of time and freedom that this generation seeks. (Cuesta, 2014, p. 18).

When evaluating a job, their interests are: for $21 \%$, that the workplace has a healthy work environment, the existence of benefits is important for $13 \%$ of them. $19 \%$ value the high salary and $27 \%$ the prestige of the job and the company. (Cuesta, 2014, p. 18).

According to INEGI, $24 \%$ of the Mexican population belongs to the Millennial generation, those born between 1981 and 1995, and generation Z, those born after 1995 represents $27 \%$ of the population. So the Millennial generation represents almost a quarter of the total population of Mexico and together with its successor generation they are more than half of the country's population. (Rodríguez, 2017, p. $1)$.

\subsection{Bureaucracy}

The word "bureaucracy", derived from "bureaucratie", has two linguistic components implicit: "bureau" which means office and "cratos" which refers to power. Therefore, bureaucracy is understood as the idea of the exercise of power through the desk of public offices. However, the term 
bureaucracy was coined by Weber himself, who derived it from the German "büro", which also means "office". In this sense, for Weber, a bureaucracy is a large organization that operates and functions on rational foundations.

Within the research, the categorical concept of the Neo-bureaucracy is proposed and used, which, as well as being a new concept proposed in the research, is the final proposal for the solution to the problem posed.

In this conceptual proposal, Neo-bureaucracy is understood as the new model of organizational structure that incorporates the deconstruction of the classic system of the Weberian bureaucracy by applying it to postmodern paradigms and the incorporation of new generational paradigms of the human resource that is in transition from its incorporation, for at least the next 30 years, the so-called Millennials.

Therefore, the Neo-bureaucracy is a formalized organization system adapted to the conditions and needs of the current environment, for its application in public administration, carrying the organizational processes in an effective and efficient way with the needs of its organizational structure formed in the formalization of processes and reengineering of the organizational culture adapted to maintain the productivity and permanence of the human resource, without compromising the administration's objectives.

\subsection{Theoretical perspectives contributed by Max Weber and Robert Merton}

According to the position on the Bureaucracy, Weber (1977), who was a German economist and sociologist and who developed the classic concept of bureaucracy, refuting, criticizing and expanding the position of Karl Marx. Weber (1977) repeatedly pointed out that capitalism was strongly influenced by ethical and religious values and that, therefore, economic relations could not only explain the relations of force in capitalism, as Marx had stated. Weber (1977), defined the bureaucracy as the most efficient form of organization taking into account the complexity of the state apparatuses, of the governmental dependencies and thinking about the needs of changing and dynamic societies.

Weber (1977) tried to prove that capitalism was strongly influenced by ethical and religious values and that, therefore, economic relations could not only explain the relations of force in capitalism, as Marx had argued. Weber defined bureaucracy as the most efficient form of organization taking into account the complexity of the state apparatuses, of the governmental dependencies and thinking about the needs of changing and dynamic societies.

The term "bureaucracy" has become part of everyday language. It is preferably used in the sphere of public organizations and administrations that constitute the State, forgetting that bureaucracies, in any of their senses, also operate in the private sector.

Weber (1977) himself considered the bureaucracy as a type of power and not as a social system. A type of power exercised by the State through its "ruling class", the ruling class.

The term bureaucracy has three connotations:

a) Bureaucracy in the sense of vulgate: its ordinary, popular and parochial meaning.

b) Bureaucracy as the dominant social class embedded in the State.

c) Bureaucracy as a model of organization, in the Weberian sense of the term.

On the other hand, Max Weber (mentioned in Santos, 2009) also established fundamental characteristics of the bureaucracy:

1. Existence of defined charges.

2. Hierarchies of authority and responsibility.

3. Personnel to carry out technical and, of course, professional functions.

4. It is governed by regulations and statutes, example: organic laws of public administration.

5. There is security in the positions and there is a possibility of promotion. 
The bureaucracy is efficient, an organization that solves social and business problems rationally and efficiently (Castoriadis, 1997). In this way, the bureaucracy is scientifically designed to function accurately, to achieve the stated objectives.

According to Weber (1977), the bureaucratic system contains the following principles:

- The performance of official functions is permanent and constant.

- Such functions are strictly executed according to the following rules:

a) The tasks of each official are delineated according to impersonal criteria.

b) The official has the authority to carry out his tasks.

c) The means of coercion available to that official are strictly limited and the conditions of their use clearly defined.

- The responsibilities and authority of each officer are part of a hierarchy of authority, with appropriate rights and duties of oversight and appeal.

- Officials do not own the resources they use in the performance of their duties, but are responsible for the use of such resources.

- Income in relation to the performance of functions is strictly separated from any other.

- Positions and / or functions do not belong to and cannot be appropriated by officials (they cannot be inherited, for example).

- The functions are performed on the basis of written documents.

Finally, the official must exercise his judgment and ability at the service of the one designated in accordance with the statutes and regulations, he is responsible for the impartial performance of his functions as established in the relevant law or regulations and must exercise them objectively, leaving aside your personal opinions or beliefs.

According to Weber (1977) himself quoted by Santos (2009), the bureaucracy can degenerate in the following ways:

- The vertical hierarchy of authority may not be explicit or delineated enough, causing confusion and conflicts of jurisdiction.

- Competencies may be unclear and used contrary to the spirit of the rules; sometimes the procedure itself can be considered more important than the decision or, in general, its effects.

- Nepotism, corruption, political confrontations and other degenerations can counteract the rule of impersonality, being able to create a recruitment and promotion system not based on merit.

- Officials can avoid responsibilities.

- The distribution of functions can be ineffective, producing excessive regulatory activity, duplication of efforts and, in general, inefficiency. (s / p).

Weber noted the fragility of the bureaucratic structure, which faces a typical dilemma: there are pressures from outside forces to force the bureaucrat to follow other rules than those of the organization; and subordinates' commitment to bureaucratic rules tends to weaken. The organization, to be efficient, demands a special type of legitimacy, rationality, discipline, and limitation in its scope.

According to Merton (1999) in his work, the bureaucratic structure and the personality, the greatest merit of the bureaucratic system is its technical efficiency, as prizes that are given for "precision, speed, expert control, continuity, discretion and optimal return. The structure is such that it approaches the complete elimination of non-rational relations, replacing them with specialized ones ".

Both the structure and the bureaucratic organization were designed to systematize the solution of problems, to deal with situations that enter the organization, in a systematic and programmed manner, which will use a minimum of material and human resources. If each situation or personal problem that the organization faced were treated as unique, it would require an amount of time and resources. But if the organizational processes become routine, the problems and demands could be solved quickly and efficiently, through the procedures established through "Standardized Operating Procedures". 
Indeed, the popular concept of bureaucracy suggests that the degree of administrative efficiency of this rational system is very low, since the ideal type of bureaucracy undergoes transformations when operated by people. In Merton's (1999) conception, the man when he participates in the bureaucracy, makes all the foresight of human behavior escape the pre-established model. The dysfunctions of the bureaucracy are verified. Therefore, each dysfunction is a consequence not foreseen by Weber's model.

The dysfunctions of the bureaucracy are:

1. Internalization of the rules and exaggerated adherence to the regulations;

2. Excess formalism and paperwork;

3. Resistance to change;

4. Depersonalization of relationships;

5. Ranking as the basis of the decision process;

6. Superconformity with routines and procedures;

7. Display of signs of authority;

8. Difficulty in customer service and conflicts with the public.

For Merton (1999) bureaucracy is a secondary group structure, destined to carry out certain activities that cannot be satisfactorily fulfilled with primary group criteria and is not as efficient, as Weber tried to demonstrate, but rather presents a series of dysfunctions, which harm functioning and lead to organizational inefficiency. (Shafritz, 1999, p. 227)

One of the main casual factors of the problem is the Closed System approach, since as a system it seeks certainty and its goal is the monolithic control network, ruling out the importance of interdependence with the environment. It understands organizations as if they were absolute entities, as if they existed in a vacuum, where it is located and without depending to fulfill its functions within the community that supports it and the environment that surrounds it.

\section{The new human capital of the bureaucratic system of public administration.}

On a regular basis, around the world, in all types of organization, there is a social phenomenon and organization, where a generational transition of workers occurs, and all members of the organization, such as the organization itself, are immersed in a paradigm shift. , since without this type of changes, the organization, by not adapting to its current environment, may become obsolete and unproductive, so it is necessary to adapt it according to the productivity of the organization, but taking into account its new internal and external elements for better operation.

\section{The perspective of Millennials in Spain}

According to statistics obtained by the written media El País (2017), in Spain, young people who were born between 1982 and 2004 (the so-called Millennials) will be more than 70\% of the workforce of the developed world in 2025 . There will probably be started to take charge of the future of humanity. In Spain, they are a generation of more than eight million people who were born in prosperity, with a considerably better political, economic and social environment than that of their parents, but who when they reached the age of majority encountered a very hard crisis that truncated the expectations of many of them. According to the FundaciónPor Causa, they are the collective of broken dreams. (s / p).

Spanish millennials want a job, but they are less in a hurry to find it and put quality and a schedule that allows them to reconcile work and personal and enjoy life, rather than a striking salary. Earning money is at the lowest echelon of your aspirations. Family, friends, the quality of work, studies or sex are above money, according to the latest survey by the Youth Observatory.

Also, they are not obsessed with owning a home or car; they are more of the culture of sharing. Except for digital devices. They want the latest mobile phone and the latest laptop, because they are essentially digital, multi-screen, and addicted to APPs and social media. They do not watch television 
much, nor do they buy newspapers, but they consider themselves well informed on the Internet. (Ayuso, 2017, s / p).

\section{The Millennial generation in Mexico}

According to a study carried out by the outsourcing company called Manpower and published by the newspaper El Siglo de Torreón, we can find various data that explain a reality about this generation, since this company hires a large amount of this new workforce, having the following data as notorious:

- Millennials make up 35\% of the world's workforce and, if motivated, are willing to work longer hours than any other generation, reveals the survey "Millennial Careers: 2020 Vision" by Manpower.

- In Mexico, these young people prioritize three things when choosing where and how to work: money, promotion opportunities and benefits, says Isaac Cortés, Trade Marketing manager at Manpower. They also value vacations and free time, a flexible work environment, and the ability to develop new skills.

- In the country $79 \%$ affirm that they work more than 40 hours a week and more than a third do it for more than 50 hours, while young people in India have the longest work week and Australians the shortest: one average of 52 and 41 hours a week, respectively.

- $42 \%$ of Mexican Millennials, in turn, occupy two or more paid jobs at the same time, the survey indicates.

- But the flip side of Millennials in the country is not very encouraging, since the unemployment rate among young people aged 15 to 24 , during the first quarter of 2016 , is $8.2 \%$, while the national rate is $3.9 \%$, indicate INEGI figures.

- In 2013, an INEGI study revealed that young people who do not study and do not work reached 6.8 million.

- This figure, according to the OECD, represents $22.4 \%$ of the population aged 15 to 29 , and is well above its world average of $14 \%$.

- The retirement of this generation will not be like that of their parents or grandparents, and these young people seem to have it clear. A third of 19,000 Manpower interviewed in 25 countries said they will work until the day they die.

- In Mexico 36\% expect to do it until after the age of 65, 19\% are projected to work after reaching the age of 70 and $8 \%$ say they will do it until the day of their death. For $12 \%$ of millennials worldwide, it is unlikely to retire someday, the survey reveals.

- In Mexico, there is a risk of facing a talent shortage crisis like the one that countries like Canada are going through. By not retaining the talents, the millennials will go to other countries that encourage their abilities and this will cause a brain drain, says the human resources specialist.

- The generation of the seventies still had access to the welfare state and to an economic model where they were responsible for guaranteeing the population the basic rights of education, housing and health. With the entry of neoliberalism, says Marcela Meneses, researcher at the UNAM Institute for Social Research, these social guarantees are dissolved and practically young people have no guaranteed rights to anything. (UNAM, August 2016).

The data, which are somewhat overwhelming, the reality that the Millennial Generation faces in Mexico, and that for this reason can come to see an adverse future and look for new work paths, in form and substance, to which we are accustomed.

\section{Limitations and antagonistic paradigmatic factors of the classic bureaucratic system of public administration today}

The bureaucratic paradigm gradually emerged in the European nation states of the early seventeenth century, thanks to the heritage tradition of imposing a formal order and creating accountability to the Royal administration. It was certainly not democratic; however, two centuries later they had become the best counterpart to our democratic institutions. 
Once the sovereign will of the people was established, to replace the cravings of the monarch, said will was to be carried out by obedient public servants whose qualities of rigor, competence and responsibility were particularly admired. The French "grand commis", the Prussian bureaucrat, the member of the English civil service were to become the personification of the general interest. Max Weber offered us the best theory of this wonderful and efficient machinery.

Democrats and Max Weber himself feared his lack of sensitivity and his possible undemocratic bias. So they set out to limit it. However, at the time no one questioned its efficiency and its enormous ability to achieve. It was considered the cornerstone of the Modern State and almost of modern civilization.

Bureaucratic patterns have become so difficult to manage that they fail to master the increasing complexity of our collective activities. Furthermore, the obedience that previously constituted the cardinal virtue that made the system work is no longer accepted willingly by citizens and public employees, who now uncontrollably demand personal freedom and individual autonomy. Complexity offers agents the opportunity to achieve freedom, while conversely, agent freedom increases complexity. Negotiated legal arrangements had always existed; however, after the bureaucracy was forced to dictate more and more rules to control complexity, respect for them has declined and the system has generated confusion and irresponsibility.

Esta situación radica en prácticas económicas y sociales, la revolución postindustrial que tiende a desplazar rápidamente a las actividades industriales por los servicios y las comunicaciones, interfiere con el conocido ciclo económico basado en la racionalización.

En lugar del ciclo producción en masa - consumo masivo, cuyo motor era y sigue siendo la racionalización, nos dirigimos gradualmente a un nuevo ciclo de alta tecnología y servicios cuyo motor es la innovación cada vez mayor. Pero la innovación es ajena al paradigma burocrático. Si hemos de promover la innovación, harán falta nuevas formas de relaciones humanas no burocráticas, pues la innovación nunca ha podido ser dirigida por órdenes. Para lograrla con suficiente rapidez, se requerirán no solamente ideas brillantes y nuevos conceptos sino también toda una cadena de relaciones ágiles, no verticales, a través de las cuales las personas puedan comunicarse con rapidez y franqueza, sobre la base de la reciprocidad. La situación de fragmentación y subordinación que implica el modelo burocrático paraliza las comunicaciones y, por ende, restringe la innovación. Es más, para ser innovadores y eficientes, los servicios tienen que depender de una comprensión cabal (que implica saber escuchar) de los clientes potenciales y reales, lo cual a su vez es impedido por el sistema de mando de la burocracia.

La administración pública no sólo participa de este paradigma, sino que queda profundamente afectada por el mismo, después de todo, sus operaciones básicas son de servicios que han de ser prestados a una sociedad de servicios. (Crozier, 1997, p. 5).

\section{Paradigmatic factors of the new reality of public administration}

The so-called knowledge society has given rise to a new world and organizational scenario where the conditions and variables for the survival and development of organizations are changing rapidly. Innovation and permanent transformation are a constant in the organizational evolution, guided and demanded by the dynamism of the current context.

In this framework, organizations are overcome their daily routines and forced to review and update their operating modalities. They must become more creative and innovative from learning and building knowledge. The first to acknowledge these needs in the face of environmental challenges were organizations from the business sector, but little by little both the public sector and non-profit organizations were equally challenged.

In recent decades, the so-called new public management has gained strength, a concept that requires the assumption of a series of principles that redefine the way of thinking about management in public organizations and imply the creation of new guidelines for institutional performance.

The model of public management is being implemented worldwide in state administrations. In the British modality it is called the Whitehall Model, the American variant refers to it as an 
entrepreneurial government and post-bureaucratic scheme and, conceived on a global scale, constitutes the OECD-Organization for Economic Development Cooperation- model that offers the notion of orientation towards client (Guerrero, 2001).

This is how emerging schemes and modernization strategies for public management have been gaining strength, which have been called by many authors as post-bureaucratic models (Guerrero, 2001, s / p). They are presented as a proposal that overcomes the limitations of the previous bureaucratic model, seeking to increase the capacity for response and continuous adaptation to organizational changes from more flexible structures.

The new conceptions emphasize the idea that public services should be guided to the service of the user (Guerrero, 2001, s / p) and present some differential characteristics:

- Results are more important than actions or tasks

- Costs are controlled

- Work routines are reviewed looking for necessary improvements and updates

- Thought is given to community service (Guerrero, 2001, s / p).

Some of its distinctive strategies at the organizational level constitute:

- The administrative flexibility necessary to increase levels of efficiency and effectiveness

- The gradual flattening of hierarchical structures

- The construction of institutional networks

- Project and program management with emphasis on results

- Management by processes rather than control over individual tasks, orientation to quality and permanent improvement (Guerrero, 2001, s / p).

It is with the previous analysis that the present investigation finds the need to search for a new model that encourages the proactivity of this generation in the public administration, due to the need for the functioning of the State structure for the good of the whole society.

\section{MeThodology}

Heuristics taken as a discipline of human rational activity that can have two meanings: the first, of a scientific nature, describes it as the method of inquiry based on experience, in order to explain specific problems, concerns the use of inductive methods rational. In this line, the contributions of the Hungarian philosopher and mathematician ImreLakatos (1983) are significant, who in his effort to refute the positivist method of falsification of his teacher Karl Poper, introduced the concepts of positive heuristics and negative heuristics, establishing what he himself called the Scientific Research Programs, currently in force in contemporary research systems.

For the development of the hermeneutics of this research work, the description and difference of the concept of Productivity in contrast to the Effectiveness and Efficiency were considered in order to manifest the methodological heuristics of Productivity and when dealing with services in what way it should be considered. For the purposes of this work, Productivity and efficiency will be used practically as synonyms, in order to avoid the confusion caused by the subtle difference between the two. On the other hand, there is also a tendency to confuse the previous concepts with that of effectiveness. For Scott (1988), effectiveness is defined as the successful achievement of established objectives. Thus, it is possible to achieve effectiveness with low or high productivity or efficiency. Likewise, it can be highly efficient or productive without having been effective. It is important to highlight this last concept, while one of the expressions of effectiveness is quality. (Ruelas-Barajas, 1993).

\section{Research questions}

How can the operation of the classic bureaucracy be adapted to current paradigms, to improve its functionality?

Will this organizational deconstruction cause a new culture within the Legislature, which will provide the permanence of Millennials in it? 
Will it make Millennials more productive and the organization meet its goals?

\section{Hypothesis}

The formulation of a deconstruction of the classic bureaucracy, adapted to current paradigms, without compromising its productivity, will help the form of government and operation of the Querétaro City Council to take place in a more effective and efficient way.

\section{General objective}

With the determination and identification of the defined stratum of the young active labor population within the bureaucratic systems of the State, it will be possible to explain the proposal of a new theoretical adjustment complementary to the current organizational systems within the bureaucratic structure, in order to effectively integrate and efficient to the young human factor, to the bureaucratic system to promote their permanence within it.

\section{Research design and instruments}

In this research work it is a category of theoretical research, according to Muñoz (2016), pure or theoretical research is delimited as such due to the type of problem statement of a factual reality, reaching philosophical speculations, locating itself in high levels of abstraction, as in the same investigation, using facts from reality for their confrontation and connection in a theoretical abstract; In the same way, the purpose of the same research is pointed out, which has the purpose of increasing knowledge by knowledge itself, seeking theoretical depth on the research topic. (p.182).

The research instruments carried out in this work were developed, for the documentary part, with the review of previous studies on the deconstruction of the bureaucracy in current paradigms, later the classic literature related to the topic of organizational theory that It is the responsibility of the bureaucracy and the structuralist school of the administration, later the discrimination of the written material not pertinent to the subject was carried out. (Galeano, 2012, p. 116).

\section{DISCUSSION OF RESULTS}

The public administration had the need for an administrative system, that is why democracy emerged, focused on the good performance, specialization and efficiency of its functions, this model proposed by theorists such as Weber and Merton seems to be definitive in the application of public organizations, However, societies are changing, which is why currently new needs arise that arise from generational, technological and scientific change.

This new generation, which is inserted in the public administration, results in a paradigmatic change in reality, considered apathetic and without commitment by some, more interested in maintaining a technological life rather than causing some social change. However, the Millennial generation has shown that social actions can also be performed without being in person during a problem; This generation has also demanded from the State the creation of legal figures that allow efficiency within the public administration, thus evidencing the weight of the contribution, via social and media networks, dominated by this generation, making changes and leanings in scales. of a legal, social, economic and political nature of the country, such is the case, that prior to the impulse of some legislative reform, it is previously disseminated in social networks, to validate its acceptance and legislative impulse thereof; This generation has also demanded from the State the creation of legal figures that allow efficiency within the public administration, such is the case of the National AntiCorruption System, but why ?, because the same ease and speed with which information circulates has allowed the management and application of resources within the public administration to be gradually made transparent.

The characteristics within the changes of the classic and deconstructed bureaucracy, and proposed in this research, Neobureaucracy is reflected in the following comparative table:

Table Paradigmatic comparative analysis of the Bureaucracy vs the Neobureaucracy.

\begin{tabular}{|c|c|c|}
\hline Paradigm & Bureaucracy & Neobureaucracy \\
\hline Use of ICT & $\begin{array}{c}\text { It was not } \\
\text { contemplated for } \\
\text { the lack of } \\
\text { development of the }\end{array}$ & $\begin{array}{c}\text { Due to social reality, the use } \\
\text { of various technological } \\
\text { mechanisms is essential for }\end{array}$ \\
\hline
\end{tabular}




\begin{tabular}{|c|c|c|}
\hline & same. & $\begin{array}{c}\text { their communication and } \\
\text { operation of the public } \\
\text { administration. }\end{array}$ \\
\hline The scientific selection of human resources & $\begin{array}{c}\text { It was a rigid } \\
\text { selection, a } \\
\text { predefined profile } \\
\text { was selected to the } \\
\text { most suitable }\end{array}$ & $\begin{array}{l}\text { It is a flexible selection, } \\
\text { where the diverse skills and } \\
\text { quality of the human } \\
\text { resource must be evaluated. }\end{array}$ \\
\hline Organizational Culture & $\begin{array}{c}\text { Based on strict } \\
\text { hierarchy and } \\
\text { control } \\
\end{array}$ & $\begin{array}{l}\text { Based on the delegation of } \\
\text { work and empowerment. }\end{array}$ \\
\hline Labor operationalapproaches & $\begin{array}{l}\text { Work for efficiency } \\
\text { and productivity } \\
\text { focused on working } \\
\text { hours }\end{array}$ & $\begin{array}{c}\text { I work for effectiveness and } \\
\text { productivity, with a focus on } \\
\text { objectives met }\end{array}$ \\
\hline Workdistribution & $\begin{array}{l}\text { Over-specialization } \\
\text { of work in the } \\
\text { organizational } \\
\text { structure }\end{array}$ & $\begin{array}{l}\text { The need for multi-tasking } \\
\text { people with diverse skills }\end{array}$ \\
\hline $\begin{array}{c}\text { Labor relations between administrations and } \\
\text { workers }\end{array}$ & $\begin{array}{c}\text { There was a } \\
\text { division and } \\
\text { distancing by levels } \\
\text { of authority }\end{array}$ & $\begin{array}{l}\text { There is a need to share } \\
\text { information and knowledge } \\
\text { delegating responsibilities } \\
\text { and working as a team }\end{array}$ \\
\hline
\end{tabular}

Comparative table of public administration in two stages and different realities called bureaucracy and neo-bureaucracy. (Own Authorship).

Based on the study and analysis carried out in the present investigation, the paradigmatic changes in the reality in which the public administration finds itself can be demonstrated, and with it the need for changes, adaptations and deconstructions, and with the above, lead to the validation of the proposed construct and called Neobureaucracy, as well as its general characteristics and necessity for this research and administrative theory.

That is why the public administration seeks to adapt to the new changes in social paradigms, and requires a new system that is more flexible to the current reality and more efficient for its operation, or else, it will face operational obsolescence in damage to it and society in general.

\section{REFERENCES}

[1] Ayuso, Javier (2017). Una generación entre dos mundos. Madrid, España: El País. Recuperado de: https://politica.elpais.com/politica/2017/03/04/actualidad/1488647914_007106.html

[2] Bongiovanni, N. C., \& Soler, C. E. (2016). Características y expectativas laborales de la generación "Y". Revista ADENAG: revista de la Asociación de docentes de Administración General de la República Argentina (ADENAG), (6), 15-20.

[3] Castoriadis, C. (1997), El avance de la insignificancia, Eudeba, Buenos Aires.

[4] Crozier, M. (Enero 1997). La transición del paradigma burocrático a una cultura de gestión pública. Publicado en la Revista del CLAD Reforma y Democracia. No. 7, Caracas.

[5] Cuesta, Eduardo. (2012). El impacto de la Generación Y en las organizaciones. EDICON. Buenos Aires.

[6] Cuesta, E. M. (2014). La Generación Y latinoamericana en las organizaciones: algunos aportes conceptuales y empíricos. Revista Gestión de las Personas y Tecnología, 7(19), 15.

[7] Galeano, M. María Eumelia (2012). Estrategias de investigación social cualitativa. El giro en la Mirada. Antioquia, Colombia. La carreta Editores.

[8] Guerrero, Omar (2001). Nuevos modelos de Gestión Pública. En: Revista Digital Universitaria, 2. UNAM.

[9] Lakatos, I. (1983). La Metodología de los Programas de Investigación Científica. Madrid. Alianza Editorial.

[10] Merton, R. (1999). La estructura burocrática y la personalidad.

[11] Muñoz Rocha, C. (2016). Metodología de la Investigación. Segunda Edición, Ed. Oxford, México

[12] Rodríguez, B. R., \& Macías, H. D. V. (2017). Diferencias generacionales en prácticas de consumo. El caso de los millennials y de la generación z. Jóvenes en la ciencia, 2(1), 597-600. 
[13] Ruelas-Barajas, E. (1993). Calidad, productividad y costos. Salud Pública de México, 35(3), 298-304. Recuperado de http://www.saludpublica.mx/index.php/spm/article/view/5660/6179

[14] Santos Hernández, M. (Julio 2009). Burocracia de Max Weber, [consultado el 27 de abril de 2018], Obtenido de: https://www.gestiopolis.com/burocracia-max-weber/

[15] Scott R., Shortell S. (1988). Organizational performance: Managing for efficiency and effectiveness. En: Shortell SM, Kaluzny A. Health are management: A text in organization theory and behavior. Segunda Edición. New York: Wiley Medical, p. 418-457.

[16] Shafritz, J. M., \& Hyde, A. C. (1999). Clásicos de la administración pública. Colegio Nacional de Ciencias Políticas y Administración pública, AC Universidad Autónoma de Csmpeche Fondo de Cultura Económica.

[17] UNAM. (Agosto 2016). Millenials, una generación sin garantías, [consultado el 20 de mayo de 2018], disponible en: http://www.iis.unam.mx/pdfs/iismedios/agosto2016/02_Millenial

[18] Weber, M. (1977). ¿Qué es la burocracia? (Trad. Rufino Arar). Buenos Aires.

\section{AUTHORS' BIOGRAPHY}

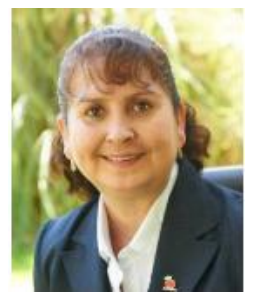

Dr. Josefina Morgan Beltrán, is a full-time professor and researcher at the Autonomous University of Querétaro, Mexico, she has a doctorate in Administration and a postdoctoral degree in Education and is a member of the National System of Researchers at Conacyt México; The lines of research are related to Organizational Competitiveness, Knowledge Management, Human Capital and Organizational Culture.

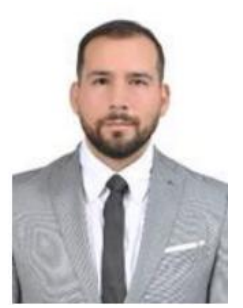

Master Luis Arturo Marín Aboytes, is a Teacher Educator at the Universidad Autónoma de Querétaro in the Law Department. He is Coordinator of Extension, Linking and Monitoring of Graduates at the Law Department of the Universidad Autónoma de Querétaro. He is a PhD in Magement Student from the Universidad Autónoma de Querétaro, Mexico. He Holds Master in Administration of Top Management, Bachelor's degree of Law and Bachelor's degree of Management. His research interests and areas of postgraduate supervision include Public Administration and Governance, Public and Corporate Finance, Economy and public policies and Administrative Systems.

Citation: Luis Arturo Marín Aboytes, \&Josefina Morgan Beltrán. "AdministrativeParadigmsonthe Human

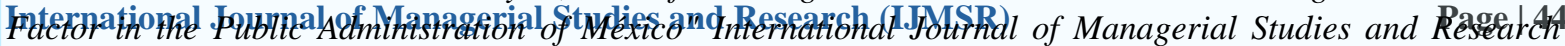
(IJMSR), vol 8, no. 6, 2020, pp. 34-43. doi: http://dx.doi.org/10.20431/2349-0381.0806004.

Copyright: () 2020 Authors. This is an open-access article distributed under the terms of the Creative 
